F105 熱光発電高効率化のための

金属被膜シリコンマイクロキャビティによる輻射スペクトル制御

\title{
Efficiency Prediction of Thermophotovoltaic with Metal-coated Silicon Microcavity
}

$\begin{array}{lll}\bigcirc & \text { 鹿島 } & \text { 玄貴（東大） } \\ \text { 正 } & \text { 鈴木 } & \text { 雄二 (東大) }\end{array}$

Genki KASHIMA, Daizen KIRIKAE, Yuji SUZUKI and Nobuhide KASAGI

Department of Mechanical Engineering, The University of Tokyo, Bunkyou-ku, Tokyo 113-8656

Ti-coated Si microcavity have been developed as a selective emitter for micro thermovoltaic power generation system. For microcavity fabricated with vacuum arc evaporation, the emittance spectra correspond well to the electromagnetic resonance modes. By using a Ge PVcell, energy conversion efficiency with the present microcavity at $900^{\circ} \mathrm{C}$ is found to be $3.4 \%$, which is in good agreement with the estimates with an equivalent circuit model. It is estimated that the energy conversion efficiency is increased to $12.3 \%$ for the emitter temperature of $1200^{\circ} \mathrm{C}$.

Key Words: Thermophotovoltaic, Selective emitter, Microcavity, Conversion efficiency

\section{1. 緒言}

携帯電子機器に用いられる Li-ion 電池に替わる超小型エ ネルギ源として，エネルギ密度の高い炭化水素燃料を用い たエネルギ源が注目されている。本研究では，可動部がな く, 補機がほとんど不要なマイクロ熱光発電システムに着 目した. 熱光発電とは, 高温の熱源から放射される輻射エ ネルギを光電変換素子により電気エネルギに変換するもの である。一般に，光電素子のバンドギャップ相当波長と輻 射スペクトルが整合しないため, 変換効率を改善するため には, マイクロキャビティなどの選択的輻射体が必要とな $ろ^{(1)}$.

効果的な輻射スペクトル制御を行うためには，キャビテ イ内部での電磁波共鳴が用いられる. 本研究では, シリコ ン基板に大面積のマイクロキャビティを形成し，金属被膜 することによって選択的放射体を試作し, 発電実験と等価 回路モデルの比較から，選択的放射体を用いた場合の熱光 発電の性能予測を行うことを目的とする.

\section{2. キャビティの製作}

キャビティ内での電磁波共鳴モードに対応する輻射率の ピークは，次式で与えられる(1).

$$
\lambda_{r}\left(n_{x}, n_{y}, n_{z}\right)=\frac{2}{\sqrt{\left(\frac{n_{x}}{L_{x}}\right)^{2}+\left(\frac{n_{y}}{L_{y}}\right)^{2}+\left(\frac{n_{z}}{2 L_{z}}\right)^{2}}}
$$

ここで, $n_{x}, n_{y}=0,1,2,3 \ldots, n_{z}=0,1,3,5 \ldots$ であり, $L_{x}, L_{y}$ はキャ ビティ開口径， $\mathrm{L}_{\mathrm{z}}$ はキャビティ哚さである。本研究では, $L_{x}=L_{y}=L_{z}=1.8 \mu \mathrm{m}$, ピッチ $2.0 \mu \mathrm{m}\left(\lambda_{\mathrm{r}}=3.2 \mu \mathrm{m}\right)$, および, $L_{x}=L_{y}=L_{z}=0.7 \mu \mathrm{m}$, ピッチ $1.0 \mu \mathrm{m}\left(\lambda_{\mathrm{r}}=1.25 \mu \mathrm{m}\right)$ のキャビテ イを製作した。

キャビティ製作方法としては，Si 基板上に電子描画装置 (ADVANTEST 製，F5112+VD01）を用いてレジストパタ ーンを形成した ${ }^{(2)}$ ，次に， $\mathrm{SF}_{6}$ プラズマを用いて $\mathrm{Si}$ 基板を エッチング加工することでキャビティを形成した．キャビ ティ壁面を平滑に保つために，Non-Bosch プロセスを用い た.キャビティ壁面に平滑な金属被膜を形成させるために,
真空アーク蒸着により $\mathrm{Ti}$ を斜め蒸着した. 最後に赤外光の 透過を防ぐために, Si 基板背面に Pt 膜を蒸着した. 図 1 に 製作したマイクロキャビティを示す.

\section{3. 輻射率計測実験}

図 2 に，輻射率計測で用いた実験系を示す。金属被膜の 酸化と熱損失を防ぐために, サンプルを真空チャンバ内に 設置し, 背面から赤外線ランプを用いて加熱した。サンプ ルの温度は放射温度計により計測した。 サンプルの輻射光 は 2 枚の凹面鏡を用いて分光器に導いた. サンプルの輻射 率 $\varepsilon_{s a m}(\lambda)$ は, 次式により求めた。 サンプルの単色輻射エネ ルギを $E_{\text {sam }}(\lambda)$, 単色輻射率を $\varepsilon_{r e f}(\lambda)$ とし, 既知の参照試料 の輻射エネルギ $E_{r e f}(\lambda)$ を用いた。

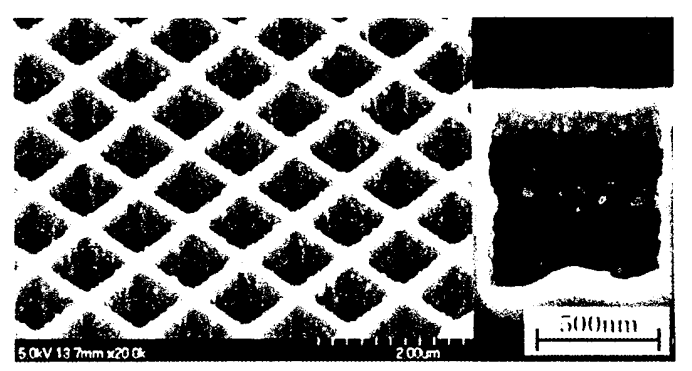

Figure 1. Ti-coated Si microcavity fabricated with vacuum arc evaporation.

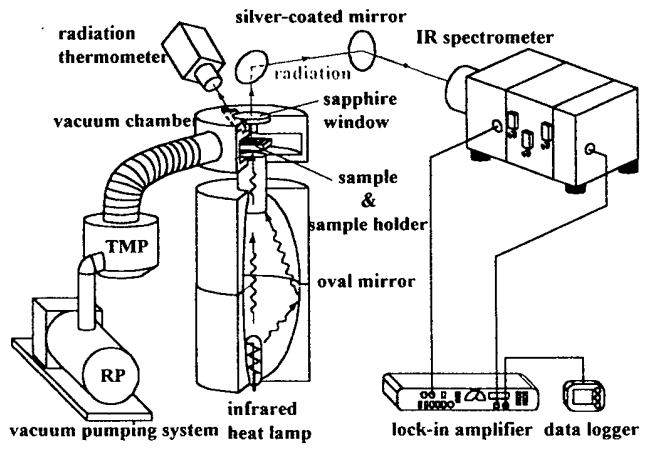

Figure 2. Experimental setup for radiation spectrum measurement. 


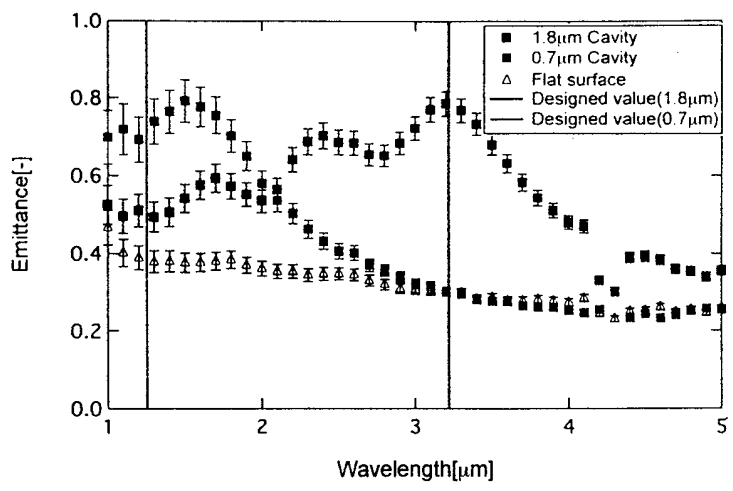

Figure 3. Emittance spectra of microcavity at $800^{\circ} \mathrm{C}$.

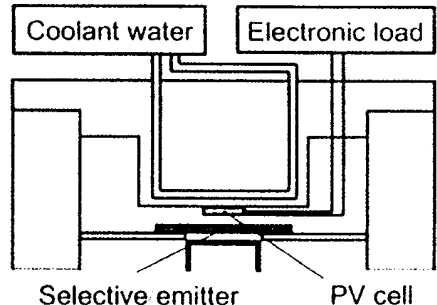

Figure 4. Experimental setup for power generation.

$$
\varepsilon_{\text {sam }}(\lambda)=\varepsilon_{\text {ref }}(\lambda) \frac{E_{\text {sam }}(\lambda)}{E_{r e f}(\lambda)} \frac{\exp \left(\frac{h c}{k T_{\text {sam }} \lambda}\right)-1}{\exp \left(\frac{h c}{k T_{r e f} \lambda}\right)-1}
$$

ここで, $h, c, k, \lambda, T$ は, それぞれ, プランク定数, 光 速, ボルツマン定数, 波長, サンプル温度である。

図 3 に $800{ }^{\circ} \mathrm{C}$ におけるサンプルの輻射スペクトルの計測 結果を示す. $L_{x}=L_{y}=L_{z}=1.8 \mu \mathrm{m}$ のサンプルでは, 輻射率 のピークが設計值の $3.2 \mu \mathrm{m}$ と一致している.また, $1.7 \mu \mathrm{m}$, $2.4 \mu \mathrm{m}$ に小さなピーク, $2.0 \mu \mathrm{m}, 2.7 \mu \mathrm{m}$ に谷が現れており, 電磁波共鳴モードと良く一致することが判る.一方, $L_{x}=L_{y}$ $=L_{z}=0.7 \mu \mathrm{m}$ のサンプルでは, 共鳴モードが設計值よりも 長波長側にずれているものの， $3 \mu \mathrm{m}$ 以上の長波長では，平 滑面と同程度の輻射率になっており，短波長側の輻射エネ ルギが増大している. $\mathrm{Ge}$ 光電素子に対する理想変換効率を, バンドギャップ波長より短い領域の輻射エネルギの割合と 定義すると，黒体の $6.1 \%$ に対し，25.5\%に改善されること が判る。

\section{4. 発電実験}

発電実験では, 輻射率測定実験の真空チャンバの蓋部を 図 4 のように変更した. サンプルの温度は, $\mathrm{K}$ 熱電対 ( $(\phi 1.0)$ をサンプルと同形状のシリコン基板により挟み，セラミッ ク接着剤により接着することで計測した. $\mathrm{Ge}$ 光電素子

(Fraunhofer ISE 製) は, 真空チャンバ蓋にサンプルと対面 になるように設置し, 背面から水冷した。形態係数を大き くするために, サンプルと光電素子の距離は $2 \mathrm{~mm}$ とした. また, 光電素子の発電特性を得るために, 電子負荷装置を 用いて I-V 曲線を測定した. またサンプルとしては, $L_{x}=L_{y}$ $=L_{z}=0.7 \mu \mathrm{m}$ のマイクロキャビティを用いた。表 1 に発電 実験の条件を示す.

図 5 に発電実験の結果を示寸。輻射体温度 $900^{\circ} \mathrm{C}$ におい て, 出力密度 $111 \mathrm{~mW} / \mathrm{cm}^{2}$, 変換効率 $\eta_{\exp }=3.36 \%$ あ゙あた。 これは Ferguson ら ${ }^{(3)}$ により提案されている等価回路モデル

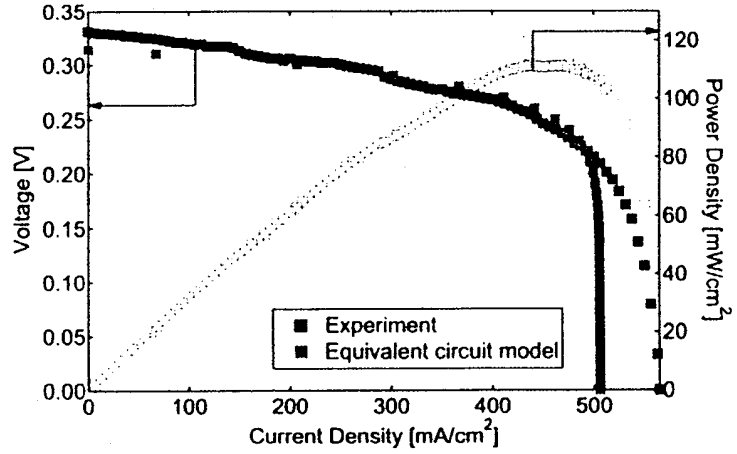

Figure 5. I-V characteristic of a Ge PVcell with present emitter at $900^{\circ} \mathrm{C}$

Table 1. Experimental condition

\begin{tabular}{|l|l|}
\hline Condition & \\
\hline Emitter areas $\left[\mathrm{cm}^{2}\right]$ & 7.0 \\
\hline Emitter temperature $\left[{ }^{\circ} \mathrm{C}\right]$ & 900 \\
\hline Ge cell areas $\left[\mathrm{cm}^{2}\right]$ & 1.6 \\
\hline Ge cell temperature $\left[{ }^{\circ} \mathrm{C}\right]$ & 29.7 \\
\hline Distance [mm] & 2 \\
\hline View factor $[-]$ & 0.22 \\
\hline
\end{tabular}

による変換効率の予測值 $\eta_{\mathrm{th}}=3.49 \%$ と良く一致しており， 等価回路モデルが妥当なモデルであることが示された。

以上より，等価回路モデルを用いることで，熱光発電シ ステムの変換効率が予測可能となった. Ge 光電素子の面積 が輻射体と同じ $7.0 \mathrm{~cm}^{2}$ と仮定した場合, 変換効率の予測値 は，黑体で $3.0 \%$ ，マイクロキャビティで $6.4 \%$ となり，マ イクロキャビティを用いることによって，2 倍近く改善で きると考えられる．さらに，輻射体の温度を $1200{ }^{\circ} \mathrm{C}$ とす ると，短波長側の輻射エネルギが増大するため，変換効率 は黒体で $7.0 \%$ ，マイクロキャビティで $12.3 \%$ と大幅に改 善できる．また，平滑面の輻射率がより低い白金被膜を施 した場合，輻射体 $900{ }^{\circ} \mathrm{C}$ で $6.8 \% ， 1200{ }^{\circ} \mathrm{C}$ で $13 \%$ と予測 される。

\section{5. 結論}

Non-bosch プロセスと真空アーク蒸着を用いて, 熱光発 電のための金属被膜シリコンマイクロキャビティを試作し, 輻射率スペクトルの計測, $\mathrm{Ge}$ 光電素子を用いた発電実験 を行った. その結果, Ti 被膜マイクロキャビティにおいて, 輻射摔ピークが電磁波共鳴モードと一致することを確認し た。また，発電実験の結果から，等価回路モデルと一致す る出力が得られ。これにより発電システムの変換効率を予 測可能であることが示された，そして，Ti 被膜の場合，輻 射体温度が $1200{ }^{\circ} \mathrm{C}$ のき，黒体放射のほぼ 2 倍となる $12.3 \%$ となることが明らかになった。

本研究の一部は, 科学技術振興機構 - 戦略的国際科学技 術協力推進事業の支援を受けた。記して感謝の意を表する.

\section{参考文献}

(1) S. Maruayama-他 3 名, Appl. Phys. Lett., 79, pp. 1393-1395, 2001.

(2) D. Kirikae ·他 2 名, Proc. 23rd IEEE Int. Conf. MEMS, pp. 1195-1198, 2010.

(3) L.G. Ferguson·他 1 名, Sol. Energy Master Cells, 39, pp. $11-18,1995$ 